\title{
A Study of the Human Factor in Industry 4.0 Based on the Automotive Industry
}

\author{
Mariusz J. Ligarski ${ }^{1, *(\mathbb{D})}$, Barbara Rożałowska ${ }^{1}$ and Krzysztof Kalinowski ${ }^{2} \mathbb{D}$ \\ 1 Faculty of Organization and Management, Silesian University of Technology, ul. Roosevelta 26-28, \\ 41-800 Zabrze, Poland; barbara.rozalowska@polsl.pl \\ 2 Faculty of Mechanical Engineering, Silesian University of Technology, ul. Konarskiego 18a, \\ 44-100 Gliwice, Poland; krzysztof.kalinowski@polsl.pl \\ * Correspondence: mariusz.ligarski@polsl.pl
}

Citation: Ligarski, M.J.; Rożałowska, B.; Kalinowski, K. A Study of the Human Factor in Industry 4.0 Based on the Automotive Industry. Energies 2021, 14, 6833. https://doi.org/ $10.3390 /$ en14206833

Academic Editors: Aleksy Kwilinski, Aleksandra Kuzior, Janusz Kotowicz and Oleksii Lyulyov

Received: 24 August 2021

Accepted: 16 October 2021

Published: 19 October 2021

Publisher's Note: MDPI stays neutral with regard to jurisdictional claims in published maps and institutional affiliations.

Copyright: (c) 2021 by the authors. Licensee MDPI, Basel, Switzerland. This article is an open access article distributed under the terms and conditions of the Creative Commons Attribution (CC BY) license (https:// creativecommons.org/licenses/by/ $4.0 /)$.

\begin{abstract}
Human factor plays an important role in the implementation of the fourth industrial revolution (Industry 4.0). The concept of Industry 4.0 is poorly researched, particularly the social aspect. The authors have conducted a study to determine the level of preparation of employees for the introduction of technological changes. This study involved conducting a survey on a sample of 453 employees based in four organizations within the automotive industry. The respondents were thereafter divided into groups based on age and positions held. The employees' knowledge of the Industry 4.0 technology was examined, and their openness to change and readiness to increase competence was determined. A causal relationship was found between knowledge and trust in technology. Employees' fears associated with production automation were discussed. A group of production workers was found to be the least prepared to implement technology changes. Actions to improve the situation and potential consequences of inadequate implementation of this technology were indicated. The findings from this study were compared with the results obtained in other countries. Special attention was paid to the limitations of this study, and we identified the necessity to conduct international comparative research on small, medium and large enterprises.
\end{abstract}

Keywords: human factor; Industry 4.0; surveys; automotive industry

\section{Introduction}

The concept of Industry 4.0 (I4.0) is a complex process involving the technological and organizational transformation of enterprises which has been made possible through the use of the latest information technology (IT) solutions and infrastructure. The process of collecting, processing and sharing data over a network communication and allowing various types of devices a significant amount of autonomy in their operation has significantly improved. 4.0 refers to a minimum of nine technologies which include Internet of Things (IoT), cloud computing, big data, autonomous robots, system integration and advanced simulation. Cybersecurity, augmented reality or additive manufacturing provide strong support for these technologies [1-3].

The implementation of I4.0-centric technologies has a strong impact on factors such as the labor market, social environment and the physical environment. Contrary to previous industrial revolutions, the current fourth revolution has a synergistic interaction of various techniques and inventions which has changed the current dynamics of human work. This change in working behaviors has resulted in the emergence of professions with a high risk of automation and as a consequence, has contributed to a decline in employment. The OECD report [4] has noted a significant share of jobs at risk of being replaced with automation and the differences in occurrence depending on the country and geographical location. In particular regions, the share of these jobs spans between $4 \%$ to $40 \%$. A greater risk is observed in regions with a high unemployment rate and low productivity. This risk is much lower in highly urbanized areas with a developed service sector and a large number 
of highly educated employees. This risk is reflected in the results of the studies published in [5]. The presented report of employee attitudes towards the future of work conducted in selected European countries shows that almost one-third (28\%) of employees in Europe fear that their work will be automated in the future. Fifteen percent of respondents believe it will happen in the next five years and $28 \%$ estimate it will be in the next ten years. Concerns about automation are most often expressed by employees in Italy $(40 \%)$ and least often in Switzerland and Poland (20\%).

The events of recent years have significantly influenced decisions regarding investments in automation. This has made a strong impact on employment policy and the qualifications required. The report in [6] shows that $43 \%$ of companies are planning to reduce their workforce due to technological integration while $34 \%$ want to increase employment for the same reason simultaneously. It has been estimated that by 2025 , the time spent by people and machines on ongoing tasks at work will be equivalent. In place of the liquidated positions, new roles will emerge with changed requirements where the most important skills needed will include critical thinking and analysis, problem-solving, the ability to work independently, and other skills such as active learning, resistance, stress tolerance and flexibility. Based on compiled data, it was found that approximately $40 \%$ of employees will require retraining. The acquired experience from working remotely has prompted $84 \%$ of employers to further digitize their work processes and significantly expand their remote working capabilities with the possibility of transferring $44 \%$ of their workforce to this style of working. Although $70 \%$ of employers are willing to invest in the development of human capital in terms of upgrading or changing qualifications, employee involvement in these processes is rather low at only $42 \%$.

The transition period between transforming workplaces and implementing new technologies will require making a series of compromise decisions that are related to supporting an increase in productivity through automation while considering the policy of changing or reducing employment terms. It is essential that effective policies such as incentivizing investment in tomorrow's markets and jobs, screening programs to protect key jobs, and improved education and training systems will need to be made available in the public sector. It is also expected that steps to improve the comfort of work and well-being of employees with respect to the change in their new automated working environment and remote work will need to be taken into consideration.

This paper, therefore, presents the results of a survey conducted among employees in four companies within the automotive industry that are located in Poland. The objectives of this study focus on the employees' knowledge about the elements of the Industry 4.0 environment, their openness to new technological solutions, and the issue of needs relating to broadening their own competence. The next section of this paper also examines the opinions on trust in technology and concerns about production automation.

\section{Literature Review}

A wave of changes influenced by I4.0 can be found in all spheres of human life ranging from the economy to social order. This has prompted many researchers and a number of institutions to conduct large-scale research on the current level of awareness about I4.0 and the hopes and fears related to them. Although the I4.0 concept is still in its early stages of existence, most companies are inclined to follow the path I4.0 has marked out and this is widely noted in work environments and in the scientific field.

\subsection{Cyber-Physical and Cyber-Human Systems}

The strong influence of the latest technologies on an industrial reality has led to the expansion of cyber-physical systems (CPS). With regard to human interaction, these systems use a separate concept-the cyber-human system (CHS). It is expected that the development of the CPS and CHS can deeply modify the production sector. There is a consensus that human labor requirements will change including the different skills that will be needed. I4.0 leads to a significant decrease in standardized low-skill activities 
and an increase in activities requiring specialized knowledge including planning, control and information technology (IT) tasks [7]. Therefore, a rise in the complexity of many professional profiles is expected which will favor the reduction of employment in positions with low qualifications and will necessitate a more intensive and time-consuming process of learning, training and continuous self-improvement. Creating new systems of work or redesigning existing systems related to the introduction of new digital technologies presents various social engineering challenges that can affect both the overall performance of the system and well-being of an individual.

Based on case studies, the authors of [8] propose a framework for designing work systems in the transition to I4.0 where human factor, ergonomics, work system modeling and designing strategies for designing industrial work systems are considered. The development and implementation of new digital solutions and technologies are based on seven stages. At each individual stage, a vision of the created work system, a value proposition to justify, the scope of work system being created, challenges, objectives, requirements and targets are developed in relation to efficiency, effectiveness, flexibility, inclusiveness, satisfaction and safety. An emphasis on understanding the socio-technical requirements in order to successfully implement I4.0 is also highlighted in [9]. Ref [10] proposes a methodology to support the design and evaluation of different variants related to human work in future work systems. The focus was on the organization of work and its evolution towards greater responsibility, the decision-making by employees, as well as a higher technological control. Whereas in [11] the potential of a human-centered design of work systems on systems that support production planning and control is described. Practical guidance on implementing CPS at different levels of advancement is also presented in [12]. In [13], a study was conducted on the ethical risks of designing symbiotic systems based on I4.0 in the context of different types of human-machine interactions. Five ethical risks to the design of symbiotic human-machine systems in I4.0 are identified where machines are assumed to be autonomous and intelligent through digitization, and the design of avatars or digital twins. Programming is regarded as common-sense and reflective behaviors are seen as barriers limiting the impact of decisions made in the face of unexpected situations or assessing them after their application, decision ambiguity, mutual interaction, master-slave dependence and emotional dependence. Researchers have identified the need to find a balance between people's competencies and the machines, to understand the environment in which they have to make decisions taking into account other decision-makers involved. The negative aspects of smart manufacturing in relation to human resources were discussed in [14]. The need to define an appropriate company strategy and mitigate the possible effects of replacing employees with robots and other automated means was highlighted. In [15] a new perspective on the central role of man in a new era of industry is presented. The integration of CHS and CPS based on five categories of activities was presented. This integration enables the synergistic cooperation of human and automated resources in the area of production, and activities considered difficult to develop on the cyber level are similar to the tasks that human beings perform naturally and vice versa.

The future role of the employee at CHS is not fully defined yet. At the existing level of development and implementation of intelligent systems, the human still remains one of the most flexible resources. In [16], a situation in the automotive industry was described where actions contrary to the current trends were observed. Due to the specific nature of car assembly and the uniqueness of the processes involved in it, it was decided that increasing the number of assembly workers in favor of the automated devices used was beneficial. Integrating the CHS and CPS environment is a natural stage in the development of systems. The direct human-machine interface plays an important role here. In [17], technological support solutions for employees are presented which represent the cyber-physical world and its interactions in the form of intelligent user interfaces. Forms of interaction in the CPS environment are discussed. In [18], issues related to human-robot cooperation are discussed from the point of view of the organization and the employee. How such new technologies can affect the well-being of employees most likely also depends on who will 
own them in the future [19]. While technological advances in the coming years are largely predictable, their implications on social impact and related regulations at the national or international level are not clearly defined.

\subsection{The Issue of Implementing the Concept of Industry 4.0}

The level of enterprise maturity and readiness to implement the I4.0 concept varies depending on the geographic location, country or level of regional development $[4,5,20,21]$. In [22-24], an extensive literature review was carried out on the implementation of the I4.0 concept. The research directions, applied standards, utilized software and hardware were summarized and the most important advantages and disadvantages were listed [23]. Some of the main advantages identified include strategic competitive advantage, organizational efficiency and effectiveness, greater organizational flexibility, production innovation, higher profitability, increased product safety and quality, customer experience, improved operations, and socio-environmental benefits. The drawbacks mentioned are a negative impact of sharing data in a competitive environment, the need for comprehensiveness, dealing with resistance from workers and trade unions, the need for a highly-skilled workforce, investments in cybersecurity, and an overall high initial cost. In [25], the results obtained from research conducted by state institutions, consortia and enterprises were analyzed particularly focusing on the leading economies of the world, i.e., USA, China, Japan, EU countries, South Africa and so on. Barriers that may threaten the achievement of a higher level of development have been highlighted. From the perspective of individual countries, other obstacles are dominating. The biggest barrier in Poland is the high investment requirements. In South Africa, the lack of digital culture and training is a concern while in Japan, the issue of unclear economic benefits from investments in digital technologies is most often raised. Additionally, the lack of adequately qualified staff is an issue that has been raised in Germany. These disparities indicate a different level of awareness and approach to issues related to I4.0. Companies try to use the I4.0 technologies that are most important to them. Several hundred companies of various sizes in Turkey from different sectors such as automotive, electronics, machinery, chemical, food and textile sectors were surveyed in [2]. The results showed that there is a significant correlation between the degree of importance and the implementation of I4.0 technologies. Of the nine technologies, cybersecurity was considered the most popular, both in terms of importance and degree of implementation. In [26] the level of preparation of SMEs for the implementation of I4.0 technology in Romania was characterized. The aim of the research was to identify stimulating factors and barriers related to the implementation of I4.0 technologies based on the opinions and observations of 176 managers from SMEs. In these managers' opinions, the vital technologies to be implemented in the future in SMEs are autonomous robots, horizontal and vertical integration, big data and analytics, IoT and cybersecurity. Considering the barriers and regardless of the industry, the following are indicated: a lack of knowledge about I4.0, emphasis on current operations at the expense of the company's development, a lack of understanding of the strategic importance of I4.0, shortage of human resources, requirements for continuous training of employees and the lack of standards. The authors of [27] present the results of a survey assessing the willingness of Hungarian companies to adapt the I4.0 technology. Questions asked focused on the collection, processing and use of data in production. Based on the responses of these Hungarian companies, it was found that most of the companies collect data at their production level although this data is not used effectively in an integrated production environment yet. The relationship between the size of a company and the implementation of I4.0 was also examined in [28]. A comparative analysis of companies in the SME sector has shown that the smaller the companies are, the greater the risk of becoming victims of the I4.0 revolution. The methodology and procedure for forecasting the performance of the system as a whole which covers all aspects of sustainability and the social and environmental aspects are presented in [29]. 


\subsection{The Human Factor in Industry 4.0}

Research on the impact of modern technologies on humans has been carried out in various aspects related to enterprises and organizations. For instance, the degree of implementation of various technologies and the level of readiness for their implementation have been studied. Due to the key role played by human resources in the production process, an essential element is the preparation of employees and their willingness to adapt to changes introduced at work positions.

In [30], an extensive list of competences necessary to work in a digitized production environment has been compiled. These competences were classified into four main categories: personal, social, methodological and technical. A general strategy for the application of the competency model was proposed to assess and develop employee competencies. A preliminary model of competence relating to the knowledge and skills required for I4.0 is described in [31]. The identified skills are classified into technical, behavioral and contextual. This model focuses on identifying areas where knowledge is lacking, and proposals for individual training courses are created. The work in [32] has identified professional competences that are related to the four successive phases of the I4.0 implementation. These competencies include: a digital representation of a factory in real-time, a horizontal integration, data analysis of vertical integration, and self-controlling manufacture and logistics. The demand for competences depends on the phase in which a given enterprise is situated. In [33], the results of the survey on key employee competences for the development of I4.0 in Poland were presented. An attempt was made to define which employee competences were important for the development of I4.0 in Poland companies and which competences should be developed. From the list of competences with the greatest importance, $69.84 \%$ of the respondents indicated the ability to solve problems and $65.08 \%$ had a personal responsibility for making decisions. In the context of development, the most mentioned skills were: the ability to coordinate work processes (95.24\%), problem-solving (93.65\%), interdisciplinary thinking and acting $(92.06 \%)$, and personal responsibility for making decisions (90.48\%). The results of research in enterprises located in Poland and the Czech Republic described in [34] indicate that one of the main barriers to the implementation of the Industry 4.0 concept is the poor awareness and knowledge of employees on this subject. It was confirmed that employees do not have adequate awareness of the principles of Industry 4.0. It was also noted that the managers lacked a clear implementation strategy for I4.0 and appropriate indicators to monitor the progress and effectiveness of its implementation. Information obtained from selected companies [35] showed that employees of Czech companies are aware of I4.0. This readiness has manifested itself mostly at the senior management level and not the middle employee level. The implementation of I4.0 principles in companies is impeded by not making the benefits clear and, in many cases, the high costs related to the use of solutions. In [36] the classification of skills and abilities needed for I4.0 in the Czech Republic with reference to other EU countries is given. The study is based on EUROSTAT, MEYS, OECD, ISCED, CZSO and WEF data from 278 companies which are mainly within the engineering sector. The 12 most important skills classified in the must have/should have/can have categories as well as technical and personal, were selected and described. Apart from IT specialist knowledge, the most important skills are organizational and procedural awareness, and self and time management. Other studies conducted in 32 companies in Turkey [37] analyzed the state of knowledge and competences among company employees as well as the training measures implemented. A different level was recorded depending on the education of the employees. It has also been shown that the level of awareness of Industry 4.0's education varies depending on the sector in which the company operates. Furthermore, the status or scope of the company's relations with foreign partners has a significant impact on the level of awareness of I4.0.

Employees' attitudes are seen to be impacted as they feel fear and a sense of threat when new solutions are introduced. Ten industrial case studies from Danish companies were analyzed in [38] where the study illustrated how the introduction of I4.0 technology can affect the well-being of humans and their system performance before, during and 
after implementation. The results show that the impact is different in each of the three phases. Despite the tendency to worry about upcoming changes and the specific situation in the company in the 'Before' phase, the excitement about new digital technologies and employee cooperation affects the balance between positive and negative feelings. In the 'During' phase, the negative aspects influencing well-being and performance outweighs the positive ones i.e., the flaws and imperfections of the initial stages of implementation and insufficient knowledge have the greatest impact on the level of frustration in employees. In the 'Post' phase, once new digital technologies are implemented, the perceived well-being and performance of employees is seen to improve. It is important to note, however, that not every negative aspect disappears in this phase. Limited standardization and insufficient management commitment were highlighted amongst the main factors. The main idea of the analysis in [39] was to understand the shift in the production paradigm from mass production to personalized production which is a characteristic of I4.0. In this context, the opportunities and threats which affect a society from functioning in an I4.0 environment were identified and social conditions were analyzed from the point of view of the consumer, producer and employee. The impact of I 4.0 on employees at the macro (i.e., market) and micro (i.e., job) level in several countries has been studied comprehensively in [24]. Summaries were prepared based on reviewing existing research work and conducting structured interviews. In [40], results from the research carried out in a production plant of a German manufacturer that is perceived as a leading factory in the field of I4.0, were presented. The concerns in this report were classified into 15 categories. The most commonly reported concerns are: employee acceptance, lacking competencies and know-how, lacking cooperation among departments, and lacking strategy in implementation. The employee acceptance concern mentioned previously can be broken down further into the following: fear of job loss, lack of experience with new technology, fear of being obsolete due to age, fear of future unknown developments, feared loss of competence, an isolated perspective rather than opinion created among peers, employees not understanding the value of data, and fears not addressed by management. An analysis of the level of satisfaction of workers actively employed in Spanish industrial companies is presented in [41]. It has been shown that the average level of satisfaction of workers employed in the Spanish industrial sector is reasonably high.

The decisive role of directed education and its impact on the level of knowledge and attitude to modern technologies is emphasized numerous times in [42-44]. In [45], opportunities and challenges for new directions in education are presented. The necessity of retraining employees and adapting their skills to changing requirements was emphasized. To meet the future needs of the economy, Education 4.0 must be viewed from a fourdimension perspective such as vocational training, entrepreneurial education, financial education and digital education. In [42], a survey was conducted to identify students' educational needs in technical faculties in Italy, and the workforce in terms of their level of knowledge and skills within the I4.0 field. The need to provide a broader and betterstructured knowledge base on the basic concepts related to the new industrial revolution at each stage of education was indicated. The authors of [46] show that a lack of knowledge about technological development leads to bias, and disinterest of decision-makers which inherently delays their understanding of I4.0. It has also been noted that overcoming prejudices and inaction is much more difficult and time-consuming than compensating for resource scarcity. The impact of training in the field of new technologies and the employee's work efficiency development was also emphasized in [44]. The development of human resources within the manufacturing and construction industries of South Africa was analyzed, and research in the South India region [47] revealed an unsatisfactory level of information on I4.0 and its components. Despite the observed positive attitude, a low level of awareness may translate into an inadequate future workforce especially in regions with increasing demographic development. A low level of awareness of I4.0 was also confirmed in [48], where the results of a survey conducted among South India's inhabitants 
were presented. This can be considered as one of the main barriers to a successful and sustainable development towards I4.0.

\section{Research Methodology}

In this study, research has been conducted in one of the key segments of the Polish automotive industry, i.e., the production of sub-assemblies, parts and accessories. The volume of exports in this area is estimated to be worth $€ 23.1$ billion which comes second to the Czech Republic, and analysts are pointing toward an upward trend. The automotive sector is therefore an important element of the Polish economy, however, there is a lack of studies linking the issues of I4.0 technology and the human factor. An applied scientific approach determines the research context related to the progressive digitalization, automation and robotization of production processes which are noticeable in the automotive industry sectors.

This research thus uses a social science methodology based on the assumption that the human factor can cause a significant impediment to the introduction of I4.0 elements. The work presented here is part of a broader study on the quality of the work environment in Industry 4.0 carried out by an interdisciplinary team comprising researchers from the Silesian University of Technology in the fields of production management and engineering, automation and robotization of technological processes, and sociology. The main research questions in this investigation relate to the technical challenges that employees and managers face as a result of the development of I4.0. These challenges have been discovered by researchers amongst other complementary aspects related to the socio-demographic and socio-legal factors, and changes within the economy and environment [30]. The aim of the research undertaken is to describe the attitudes of employees and managers towards technical and technological change. It is also important for the research to present the relationships that influence different approaches to work. These approaches are limited to three main issues (Figure 1). The first issue is linked to the employees' knowledge, which is an essential part of an organization's resources, as well as their ability to acquire new skills. The second issue focuses on the employees' openness to change and the possibility of incorporating various elements of Industry 4.0 technologies into their workspace. Lastly, the overall trust in technology is considered. As a whole, the three issues to be addressed are important tools for employees working in Industry 4.0.

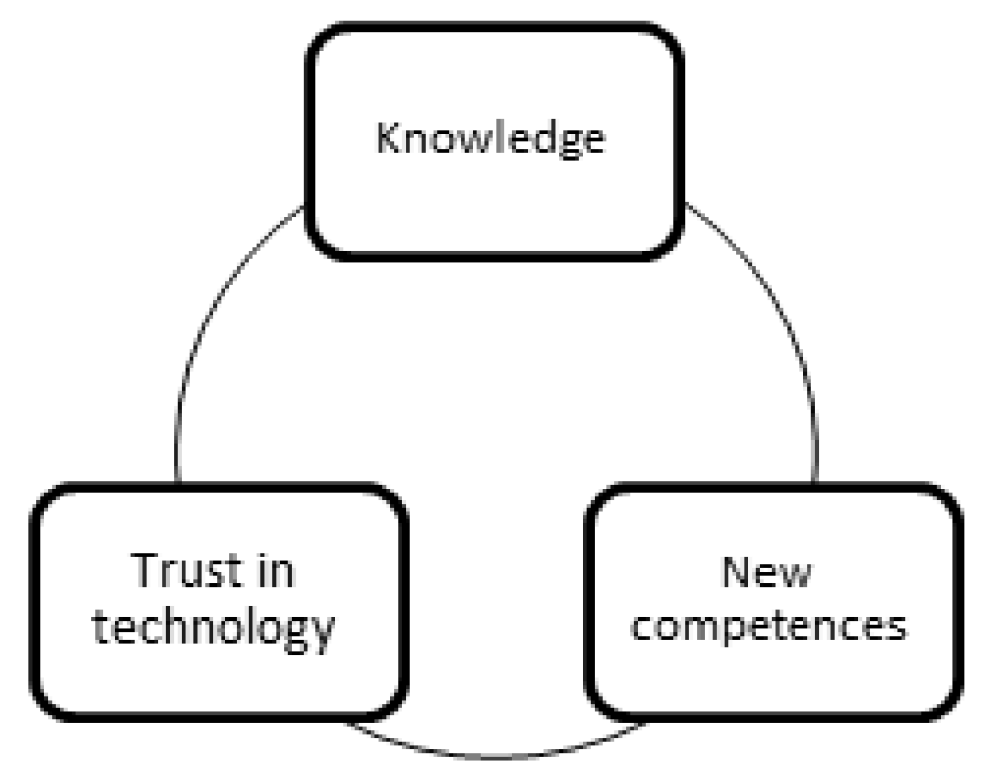

Figure 1. Research assumptions. Source: the authors.

Findings from this investigation answer the following research questions: 
- (Q1) Are employees knowledgeable about the phenomena surrounding work in an I4.0 environment? Do employees in engineering, manufacturing and management have the same level of knowledge?

- (Q2) Do employees perceive elements of the Industry 4.0 environment in their work and do they see the possibility of using particular technologies in the near future?

- (Q3) Do employees in the surveyed companies display a positive attitude towards acquiring new knowledge? Do position and age differentiate responses?

- (Q4) How do employees perceive ongoing automation processes? Is automation perceived as a factor supporting work or as a threat to jobs? What is the stated confidence in robots collaborating with humans?

The detailed research model is presented in Figure 2.

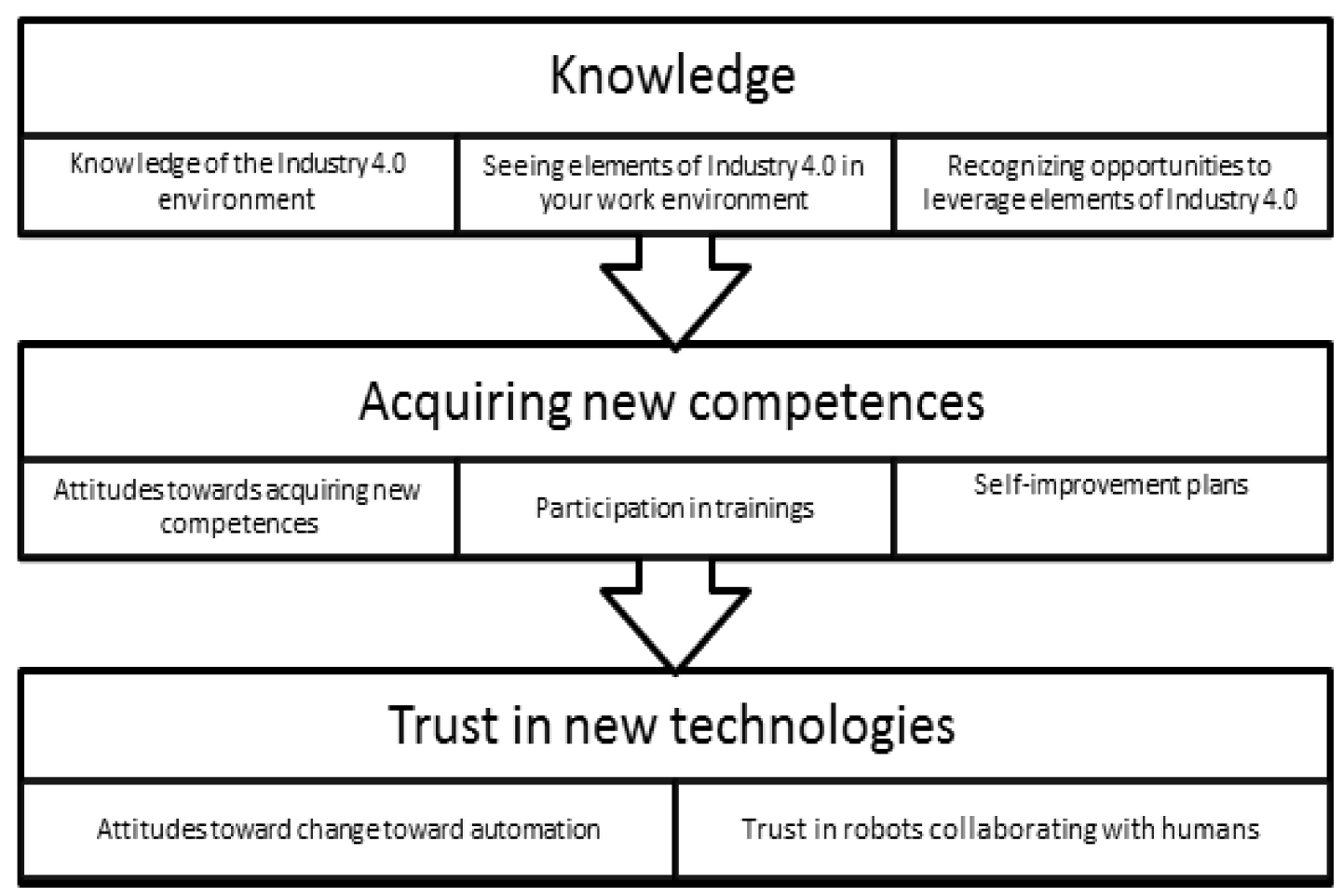

Figure 2. Research model. Source: the authors.

Due to the research objectives, the sample selection used in the study was based on two stages. Firstly, four automotive-related companies were specifically selected from Silesia, an industrialized region in southern Poland. These companies were qualified for the study based on their progressing automation and robotization processes (companies A, B, C) and also because of the close relationship with monitoring current trends in the management of automotive industry companies (company D).

The unit of analysis, however, was not the companies, but the individuals who were part of the selected organizations. The consent of the management of the aforementioned enterprises was obtained to conduct the scientific research in their organizations, as well as the promise of assistance in reaching the employees. Information about anonymity and the scientific purpose of the research was given in the introduction of the survey questionnaire. It was also allowed to return questionnaires that were not fully completed. The sample is therefore not random due to the participation of only those who were willing to participate. This research survey lasted for four months from November 2018 to February 2019. The list of questionnaires received back from carrying out the survey is presented in Table 1. A total of 453 completed questionnaires were obtained. 
Table 1. Information about the companies in which the survey was conducted.

\begin{tabular}{|c|c|c|c|}
\hline Company & Field of Activity & $\begin{array}{l}\text { Number of Surveys } \\
\text { Conducted }\end{array}$ & $\begin{array}{l}\text { Number of } \\
\text { Employees }\end{array}$ \\
\hline A & $\begin{array}{c}\text { Manufacture of automotive lamps and } \\
\text { reflectors }\end{array}$ & 99 & 800 \\
\hline $\mathrm{B}$ & Windscreen production & 207 & 900 \\
\hline $\mathrm{C}$ & $\begin{array}{l}\text { Manufacture of automotive electronics } \\
\text { Research and development and }\end{array}$ & 59 & 320 \\
\hline \multirow[t]{2}{*}{$\mathrm{D}$} & $\begin{array}{l}\text { production in the field of automobile } \\
\text { construction }\end{array}$ & 88 & 380 \\
\hline & Total & 453 & 2400 \\
\hline
\end{tabular}

The survey questionnaire consisted of a total of 34 questions on different aspects of working in an industrial environment and 4 questions on the demographic and social characteristics of the respondents. The paper presents data extracted from 9 closed-ended indicator questions on issues of knowledge, openness to new competences and trust in technology, which were then correlated with independent variables such as position held and age. A 5-point Likert scale was used in answering the questions.

The accuracy of the indicators used was based on face validity, criterion-related validity, construct validity and content validity. An initial pilot study was conducted to validate the research tool. The questionnaire was tested on a small group of respondents (20 people) to check that the questions were understandable and that respondents did not have difficulty in answering.

\section{Results}

\subsection{Knowledge}

A survey was conducted in four automotive organizations with a sample of $453 \mathrm{em}$ ployees who showed a varying knowledge of Industry 4.0 technologies. A summary of the responses for each technology for all individuals surveyed is given in Table 2. To better understand the terminology used in the survey, a brief description explaining each term was given to the respondents, and the descriptions were placed next to each technology. Basic statistics from the survey are also summarized in Table 2. Analyzing the obtained results has shown that the overall knowledge about particular technologies is at an average level. The employees in the surveyed organizations showed the highest level of knowledge on the Internet of Things (3.21). Very similar levels of knowledge were identified for three technologies: integrated manufacturing systems, computer simulation and autonomous robots. It is worth noting that knowledge on big data and augmented reality was rated at the lowest level. These results hence confirm that the declared knowledge of all respondents is at an average level while visible differences in the understanding of individual technologies can be seen. This may be due to the varying preparation of employees and the diverse types of experience the employees have had with particular technologies in a given workplace.

Table 2. Summary of responses regarding general knowledge of specific Industry 4.0 technologies and basic statistics.

\begin{tabular}{|c|c|c|c|c|c|c|c|c|c|c|c|}
\hline $\begin{array}{l}\text { Answers } \\
\text { Technology }\end{array}$ & $\stackrel{\circ}{\stackrel{2}{Z}}$ & 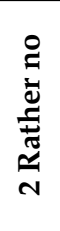 & 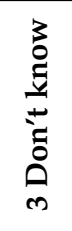 & 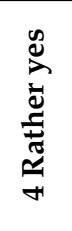 & $\overbrace{\text { in }}^{\infty}$ & $\sum_{\Sigma}^{\Xi}$ & 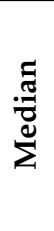 & 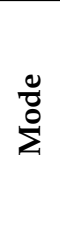 & 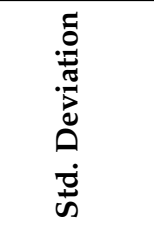 & 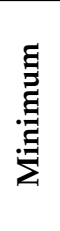 & 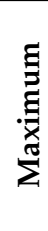 \\
\hline $\begin{array}{l}\text { Cloud computing (processing data on } \\
\text { external servers on the Internet) } \mathrm{N}=446\end{array}$ & 93 & 88 & 97 & 116 & 52 & 2.88 & 3 & 4 & 1.3217811 & 1 & 5 \\
\hline $\begin{array}{l}\text { Augmented reality (superimposing elements } \\
\text { of the virtual world on reality) } \mathrm{N}=447\end{array}$ & 113 & 83 & 121 & 84 & 46 & 2.70 & 3 & 3 & 1.3083273 & 1 & 5 \\
\hline
\end{tabular}


Table 2. Cont.

\begin{tabular}{|c|c|c|c|c|c|c|c|c|c|c|c|}
\hline $\begin{array}{l}\text { Answers } \\
\text { Technology }\end{array}$ & $\stackrel{0}{Z}$ & 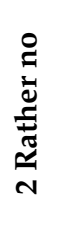 & 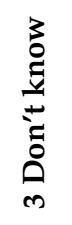 & 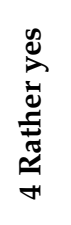 & $\overbrace{\text { in }}^{\infty}$ & $\sum_{\Sigma}^{\Xi}$ & 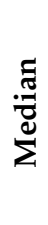 & $\frac{0}{\tilde{0}}$ & 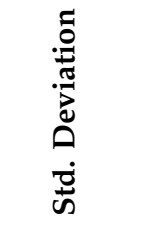 & 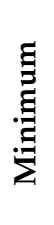 & 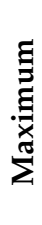 \\
\hline $\begin{array}{l}\text { Autonomous robots (a device that replaces } \\
\text { humans in performing certain activities, able } \\
\text { to adapt itself to the environment) } N=447\end{array}$ & 80 & 68 & 96 & 131 & 72 & 3.11 & 3 & 4 & 1.3410208 & 1 & 5 \\
\hline $\begin{array}{l}\text { Computer simulations (simulations of } \\
\text { phenomena performed using a mathematical } \\
\text { model) } \mathrm{N}=448\end{array}$ & 89 & 57 & 101 & 114 & 87 & 3.12 & 3 & 4 & 1.394083 & 1 & 5 \\
\hline $\begin{array}{l}\text { Integrated production systems (all basic } \\
\text { functions and process elements integrated by } \\
\text { means of a computer system) } N=447\end{array}$ & 77 & 66 & 98 & 136 & 70 & 3.13 & 3 & 4 & 1.3249793 & 1 & 5 \\
\hline $\begin{array}{l}\text { Internet of things (technological devices and } \\
\text { work tools that can collect, process and } \\
\text { exchange data with each other) } N=448\end{array}$ & 70 & 67 & 94 & 133 & 84 & 3.21 & 3 & 4 & 1.3346834 & 1 & 5 \\
\hline $\begin{array}{l}\text { Additive technologies } \\
\text { (3D printing) } \mathrm{N}=448\end{array}$ & 110 & 78 & 91 & 110 & 59 & 2.84 & 3 & $\begin{array}{c}1 \\
\text { and } \\
4\end{array}$ & 1.3814547 & 1 & 5 \\
\hline $\begin{array}{l}\text { Big data (computer processed large data sets) } \\
\qquad \mathrm{N}=445\end{array}$ & 106 & 92 & 131 & 79 & 37 & 2.66 & 3 & 3 & 1.2482075 & 1 & 5 \\
\hline
\end{tabular}

Interesting information is given from comparing the responses of three specific groups of employees surveyed i.e., the managers, engineering staff and production employees. In this case study, the managers are classified as managers at any level, engineers are classified as white-collar workers working in engineering while the production workers are classified as blue-collar workers working in manufacturing. A summary of the declared "yes" and "rather yes" answers from these three groups of employees is presented in Table 3.

Table 3. Knowledge of various aspects of Industry 4.0 vs. job position.

\begin{tabular}{cccc}
\hline $\begin{array}{c}\text { Employee Group } \\
\text { Technology }\end{array}$ & Managers & $\begin{array}{c}\text { Engineering } \\
\text { Staff }\end{array}$ & $\begin{array}{c}\text { Production } \\
\text { Workers }\end{array}$ \\
\hline Cloud computing & 48.7 & 54.8 & 19.2 \\
Augmented reality & 42.1 & 36.3 & 18.1 \\
Autonomous robots & 56.6 & 60.1 & 28.8 \\
Computer simulations & 50.0 & 67.3 & 23.6 \\
Integrated production systems & 55.3 & 63.1 & 28.3 \\
Internet of things & 50.0 & 69.6 & 30.2 \\
Additive technologies & 36.8 & 60.7 & 18.1 \\
Big data & 32.9 & 39.9 & 12.2 \\
\hline
\end{tabular}

From analyzing the results obtained, one can clearly see differences between the three studied groups of employees. The highest knowledge of Industry 4.0 technology was demonstrated by engineering staff followed by the executives while the production workers showed the lowest knowledge across all technologies. Engineering staff displayed the highest knowledge in seven of the eight technologies presented. For instance, in the areas of cloud computing, autonomous robots and big data, the knowledge of the engineering employees was rated higher than that of executives. It was only in the augmented reality technology that executives had a higher knowledge. By virtue of their job role, engineering employees have a high level of knowledge that is essential for their daily work and this group is most likely to use this knowledge. It was surprising to learn that the management 
group showed a higher knowledge in the augmented reality field. The executives' group, on the other hand, revealed the highest level of knowledge in the areas of autonomous robots, integrated manufacturing systems, Internet of Things and computer simulation. Their relatively high level of knowledge in cloud computing and big data may be attributed to their use of diverse data for management and decision-making tasks. In general, managers have a reasonably high knowledge of Industry 4.0 technologies but noticeably lower (except in one area) than engineering staff. An attempt can be made to explain this situation. Nowadays, managerial knowledge and skills are required to manage employees efficiently even though factual knowledge of the processes involved may be at a slightly lower level. In all surveyed companies, the lowest level of knowledge was shown by production workers. Compared to the other studied groups, the knowledge of production workers in all analyzed technologies was significantly lower. Production workers are perceived to be more focused on their work and only possess the necessary knowledge and skills required to perform their daily tasks. This surveyed group showed the lowest level of knowledge in the areas of big data, augmented reality and incremental technologies which confirms the previously presented regularity. Serial employees focus only on the knowledge they need to do their jobs at that time. By taking into account the challenges posed by Industry 4.0 and the need to have an appropriate level of knowledge in its various technologies, it is essential to know whether organizations properly train their employees to prepare them for a change in working conditions which may include the automation and robotization of processes.

\subsection{Support for Working with Technology}

Useful information can be gleaned from comparing the extent to which the individual groups of employees are supported in the use of Industry 4.0 technologies. Based on the three groups of surveyed employees, a comparative analysis on what extent the work is supported and to what extent it could be supported for each technology is presented in Table 4.

Table 4. Workplace vs. use of various aspects of Industry 4.0 and stated need for it.

\begin{tabular}{|c|c|c|c|c|c|c|}
\hline \multirow{2}{*}{$\begin{array}{c}\text { Employee Groups } \\
\text { Technology }\end{array}$} & \multicolumn{2}{|c|}{ Managers } & \multicolumn{2}{|c|}{ Engineering Staff } & \multicolumn{2}{|c|}{ Production Workers } \\
\hline & Supported & $\begin{array}{l}\text { Could be } \\
\text { supported }\end{array}$ & Supported & $\begin{array}{l}\text { Could be } \\
\text { supported }\end{array}$ & Supported & $\begin{array}{l}\text { Could be } \\
\text { supported }\end{array}$ \\
\hline Cloud computing & 21.1 & 27.6 & 19.9 & 36.9 & 4.5 & 6.0 \\
\hline Augmented reality & 14.5 & 18.7 & 4.8 & 23.2 & 5.0 & 5.6 \\
\hline Autonomous robots & 27.6 & 33.3 & 12.5 & 21.0 & 27.7 & 31.7 \\
\hline Computer simulations & 38.2 & 47.4 & 42.9 & 59.5 & 16.5 & 22.9 \\
\hline Integrated production systems & 43.4 & 47.3 & 30.5 & 36.9 & 29.9 & 28.3 \\
\hline Internet of things & 26.3 & 31.6 & 34.7 & 41.1 & 12.4 & 13.5 \\
\hline Additive technologies & 18.7 & 22.4 & 14.5 & 27.4 & 8.0 & 13.5 \\
\hline Big data & 22.4 & 22.4 & 21.7 & 27.4 & 4.0 & 13.4 \\
\hline
\end{tabular}

The executives' group has been shown a higher level of support for their work with Industry 4.0 technologies than engineering employees. In six technologies, this declaration is evidently higher except in the computer simulation and the Internet of Things technologies which are at a lower level. This result is surprising considering an earlier study stated that, engineering employees declared a higher knowledge of Industry 4.0 technologies. The only exception is the use of autonomous robots, where the executives' group of workers are more familiar with to a higher degree than engineering workers. The second most frequently used technology by production workers is the integrated production systems. Again, the premise that production workers only use technologies they need to perform their job is confirmed.

In terms of introducing changes related to the Industry 4.0 technologies, engineering employees and managers are most open to making changes related to I4.0. In the six technologies presented, engineering employees declared more receptivity to introducing 
changes. In two technologies, i.e., the integrated manufacturing systems and autonomous robots, managers have shown a higher interest in making changes. A thorough analysis on the differences with each technology has illustrated a demand for making changes in two of the three groups of employees. The highest demand for introducing changes involved computer simulations which were declared by the engineering employees' group. This group of employees has shown a great interest in making changes using technologies such as the Internet of Things, integrated manufacturing systems and cloud computing. While the executives' group has reported the highest demand for change in computer simulation and integrated manufacturing systems, the engineering employees have geared towards a demand for change in the areas of autonomous robots and integrated manufacturing systems. These survey results are reasonable particularly due to the specificity of work carried out by these different groups of employees. The group that is least open to change is the production workers. It was discovered, however, that the production workers are more willing to adapt to and accept changes in the autonomous robots, integrated manufacturing systems and computer simulations technologies. In the other areas of technology, the production workers are seen to be less willing to make changes.

\subsection{New Competences}

In the changing work environment of Industry 4.0, attitudes towards acquiring new knowledge are extremely important. The main variable that differentiates the responses regarding the importance of acquiring new competencies is age, as shown in Table 5. In a group of young workers under the age of 33, the percentage of those who considered acquiring new came up to over $76 \%$ compared to workers in the oldest age group with a percentage of about $43 \%$.

Table 5. Importance of acquiring new competences vs. age in $\%(\mathrm{~N}=450)$.

\begin{tabular}{ccccc}
\hline & $\mathbf{1 8 - 3 3}$ & $\mathbf{3 4 - 4 9}$ & $\mathbf{5 0}$ and More & Total \\
\hline Definitely important & 40.91 & 31.84 & $\mathbf{1 5 . 6 9}$ & 34.00 \\
Rather important & 35.35 & 38.81 & 27.45 & 36.00 \\
Rather unimportant & 8.08 & 9.45 & 27.45 & 0.89 \\
Definitely not important & 2.02 & 2.99 & 1.96 & 2.44 \\
Hard to say & 13.64 & 16.91 & 27.45 & 16.67 \\
Total & 100 & 100 & 100 & 450 \\
\hline
\end{tabular}

The importance of continuing education is perceived differently at various workplaces as depicted in Table 6. Employees working in engineering positions are the most receptive to acquire new competences. Over $86 \%$ of the respondents within this group indicated a positive attitude towards this issue i.e., they responded with "definitely important" and "rather important" in the survey. On the other hand, 64\% of the managers' group and about $58 \%$ of the production employees are receptive to acquiring new competences.

Table 6. Importance of acquiring new competences vs. position in \% $(\mathrm{N}=448)$.

\begin{tabular}{ccccc}
\hline & Managers & $\begin{array}{c}\text { Production } \\
\text { Workers }\end{array}$ & $\begin{array}{c}\text { Engineering } \\
\text { Staff }\end{array}$ & Total \\
\hline Definitely important & 36.84 & 19.70 & 49.11 & 33.71 \\
Rather important & 27.63 & 38.92 & 37.28 & 36.38 \\
Rather unimportant & 21.05 & 12.81 & 3.55 & 10.71 \\
Definitely not important & 2.64 & 3.94 & 0.59 & 2.46 \\
Hard to say & 11.84 & 24.63 & 9.47 & 16.74 \\
Total & 100 & 100 & 100 & 100 \\
\hline
\end{tabular}

In a changing work environment, acquiring new knowledge is essential. However, the survey results showed that every 10th respondent implied that their company did not provide employees with access to training. This phenomenon is observed more often 
among the youngest group of employees and employees working directly in production. In Table 3, it is observed that the older employees rarely declared the lack of possibility to participate in trainings. High readiness to participate in trainings is observed, especially among young workers and in the white-collar engineer group. In Tables 7 and 8, the percentage of positive answers i.e., "definitely willing" and "rather willing" are shown to be about $64 \%$ and $76 \%$ respectively.

Table 7. Attitude towards participation in training vs. age in $\%(\mathrm{~N}=449)$.

\begin{tabular}{ccccc}
\hline & $\mathbf{1 8 - 3 3}$ & $\mathbf{3 4 - 4 9}$ & $\mathbf{5 0}$ and More & Total \\
\hline Definitely willing & 33.33 & 29.00 & 9.80 & $\mathbf{2 8 , 7 3}$ \\
Rather likely & 30.30 & 29.00 & 39.22 & 30.73 \\
Rather reluctantly & 8.08 & 11.00 & 15.69 & 10.25 \\
Strongly reluctant & 3.54 & 6.00 & 7.84 & 5.12 \\
Hard to say & 12.63 & 14.50 & 25.49 & 14.92 \\
No training & 12.12 & 10.50 & 1.96 & 10.25 \\
Total & 100 & 100 & 100 & 100 \\
\hline
\end{tabular}

Table 8. Attitude towards participation in training vs. position in $\%(\mathrm{~N}=447)$.

\begin{tabular}{ccccc}
\hline & Managers & $\begin{array}{c}\text { Production } \\
\text { Workers }\end{array}$ & $\begin{array}{c}\text { Engineering } \\
\text { Staff }\end{array}$ & Total \\
\hline Definitely willing & 30.26 & 13.79 & 45.24 & 28.41 \\
Rather likely & 30.26 & 31.53 & 30.36 & 30.87 \\
Rather reluctantly & 7.89 & 13.79 & 6.55 & 10.07 \\
Strongly reluctant & 7.89 & 6.40 & 2.37 & 15.15 \\
Hard to say & 13.17 & 22.17 & 7.74 & 15.21 \\
No training & 10.53 & 12.32 & 7.74 & 10.29 \\
Total & 100 & 100 & 100 & 100 \\
\hline
\end{tabular}

The results of the survey have shown that employees in the automotive industry are open to improving their competences independently. This response is majorly observed as almost $85 \%$ of the surveyed people within the engineering employees' group and over $65 \%$ of the management group -gave positive answers, shown in Table 9 . Table 10 displays the results for different age groups where a dependence on the willingness to improve competences unaided with age is evident.

Table 9. Declared plans to improve competencies in-house vs. position in \% $(\mathrm{N}=446)$.

\begin{tabular}{ccccc}
\hline & Managers & $\begin{array}{c}\text { Production } \\
\text { Workers }\end{array}$ & $\begin{array}{c}\text { Engineering } \\
\text { Staff }\end{array}$ & Total \\
\hline Yes & 65.79 & 56.93 & 83.93 & 68.61 \\
No & 34.21 & 43.07 & 16.07 & 31.39 \\
Total & 100 & 100 & 100 & 100 \\
\hline
\end{tabular}

Table 10. Declared plans to improve competences on their own vs. age in $\%(\mathrm{~N}=448)$.

\begin{tabular}{ccccc}
\hline & $\mathbf{1 8 - 3 3}$ & $\mathbf{3 4 - 4 9}$ & $\mathbf{5 0}$ and More & Total \\
\hline Yes & 74.11 & 69.00 & 45.10 & 68.53 \\
No & 25.89 & 31.00 & 54.90 & 31.47 \\
Total & 100 & 100 & 100 & 100 \\
\hline
\end{tabular}

Further research will show whether this trend will continue among older workers. However, the results from the research survey show that active and open attitudes prevail among automotive workers. More particularly are the group employees with higher education who work in engineering positions. As shown earlier in Table 3, this group 
already showed an adequate level of knowledge on the specifics of work within Industry 4.0 and therefore understands the requirements that employees face.

\subsection{Confidence in New Technologies}

The dynamic automation of production processes can be perceived by employees as a threat. The survey asked respondents about their perception of increasing automation within the company they work for (Figure 3).

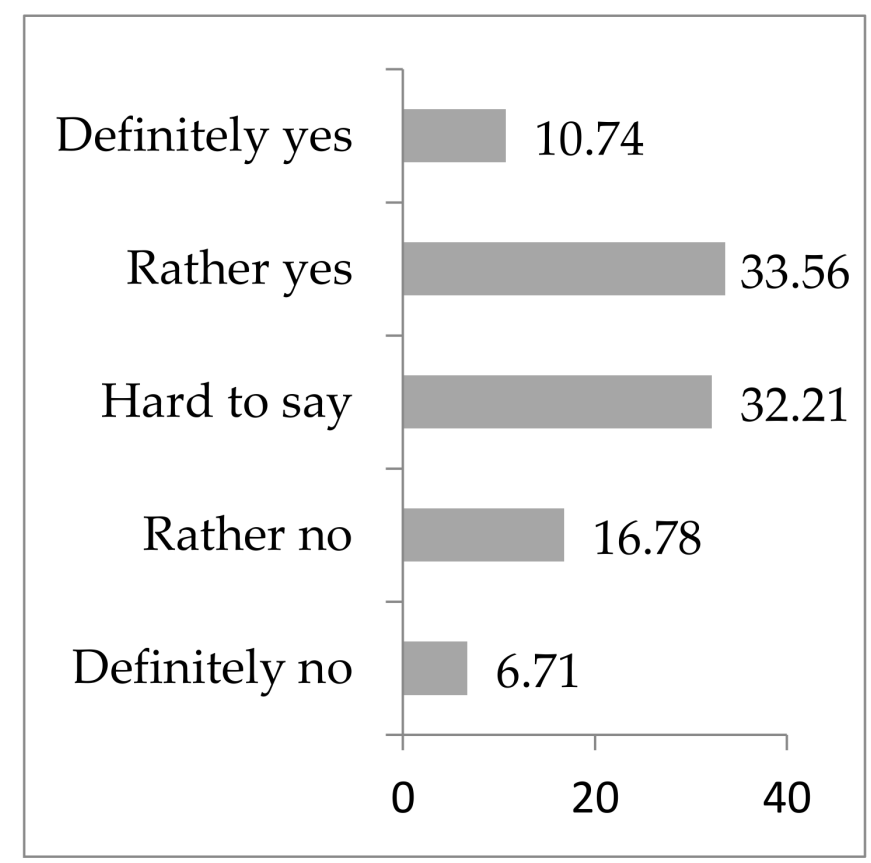

Figure 3. The occurrence of changes towards increased automation in the company in the opinions of employees.

About half of the respondents responded positively while around a quarter of the respondents do not perceive an increase in automation in their work environments. A large percentage of "hard to say" responses shows a poor orientation on this issue.

In this case study, it was also important to find out the general attitude of employees towards automating processes in the plant. The question on this topic was posed indirectly by probing the atmosphere that came up as a result of progressive changes. Taking into account the job position and age variable, the results of the study are presented in Tables 11 and 12.

Table 11. Declared attitudes towards automation in the workplace vs. position in $\%(\mathrm{~N}=437)$.

\begin{tabular}{ccccc}
\hline & Managers & $\begin{array}{c}\text { Production } \\
\text { Workers }\end{array}$ & $\begin{array}{c}\text { Engineering } \\
\text { Staff }\end{array}$ & Total \\
\hline Strongly positive & 5.33 & 4.00 & 7.41 & 5.49 \\
Rather positive & 42.33 & 41.00 & 29.63 & 37.07 \\
Rather negative & 16.00 & 12.50 & 8.64 & 13.04 \\
Strongly negative & 6.67 & 6.00 & 1.23 & 4.35 \\
Hard to say & 30.67 & 36.50 & 53.09 & 41.65 \\
Total & 100 & 100 & 100 & 100 \\
\hline
\end{tabular}


Table 12. Declared attitudes towards automation in the workplace versus age in $\%(N=438)$.

\begin{tabular}{ccccc}
\hline & $\mathbf{1 8 - 3 3}$ & $\mathbf{3 4 - 4 9}$ & $\mathbf{5 0}$ and More & Total \\
\hline Strongly positive & 6.77 & 2.56 & $\mathbf{1 1 . 7 6}$ & 5.48 \\
Rather positive & 34.90 & 42.05 & 25.49 & 36.99 \\
Rather negative & 9.37 & 14.36 & 9.80 & 11.64 \\
Strongly negative & 5.21 & 4.11 & 1.97 & 4.34 \\
Hard to say & 43.75 & 36.92 & 50.98 & 41.55 \\
Total & 100 & 100 & 100 & 100 \\
\hline
\end{tabular}

Interestingly, managers and production workers believe that the evaluation of ongoing automation processes is more positive than it is in the case of engineering and mechanical workers. The percentages in this case are $48 \%, 45 \%$, and $37 \%$, respectively. Table 12 shows the results by age group. Respondents between the ages of 34 and 49 expressed the strongest opinions as they showed a positive experience of making changes ( $45 \%$ of responses). At the same time, other groups were described as negatively perceived by other employees (18\%).

In the oldest age group, growing uncertainty about the assessment of the ongoing changes towards automation was evident as more than half of the people in this bracket were unable to determine whether the ongoing processes were positive or negative.

In addition, respondents were asked to express their opinion on trusting robots to cooperate with humans. The responses received showed that the lowest level of trust was expressed by workers employed in production jobs (see Table 13). $26 \%$ of respondents in the production workforce are observed to completely trust robots or trust robots to a high degree compared to the $37 \%$ of managers and $40 \%$ of engineering workers. Production workers are also more likely than others to distrust robots at work as $38 \%$ of the responses received were negative. This result implies that knowledge of the technical aspects of manufacturing 4.0 increases trust in machines and equipment working together with humans.

Table 13. Confidence in robots collaborating with humans on the job vs. position in $\%(N=439)$.

\begin{tabular}{ccccc}
\hline & Managers & $\begin{array}{c}\text { Production } \\
\text { Workers }\end{array}$ & $\begin{array}{c}\text { Engineering } \\
\text { Staff }\end{array}$ & Total \\
\hline I trust completely & 4.00 & 3.05 & 3.59 & 3.42 \\
I trust very much & 33.33 & 22.84 & 36.53 & 29.84 \\
I trust moderately & 46.67 & 36.04 & 37.12 & 38.27 \\
I do not trust to a high degree & 14.67 & 25.89 & 16.77 & 20.50 \\
I do not trust at all & 1.33 & 12.18 & 5.99 & 7.97 \\
Total & 100 & 100 & 100 & 100 \\
\hline
\end{tabular}

The highest level of trust is observed in the youngest group up to the age of 33 where $37 \%$ stated that they trust robots completely or to a great extent (Table 14). This is followed by $31 \%$ of respondents within the age range of 34 to 49 years old and $24 \%$ in the oldest group. Interestingly, the highest level of trust in robots was expressed by one in ten people in the last age group. This is probably due to the positive experiences that these individuals have had with this type of technology. From the survey results, it is also clear that the willingness to cooperate with robots increases with age, for example, more results with "I moderately trust" and negative answers were received. 
Table 14. Confidence in robots collaborating with humans on the job vs. age in $\%(N=441)$.

\begin{tabular}{ccccc}
\hline & $\mathbf{1 8 - 3 3}$ & $\mathbf{3 4 - 4 9}$ & $\mathbf{5 0}$ and More & Total \\
\hline I trust completely & 1.52 & 3.60 & 10.00 & 3.40 \\
I trust very much & 35.53 & 27.84 & 14.00 & 29.71 \\
I trust moderately & 36.55 & 39.18 & 44.00 & 38.55 \\
I do not trust to a high degree & 18.27 & 20.62 & 30.00 & 20.63 \\
I do not trust at all & 8.13 & 8.76 & 2.00 & 7.71 \\
Total & 100 & 100 & 100 & 100 \\
\hline
\end{tabular}

Younger people have shown less distrust in collaborating with robots. It is reasonable to assume that this result depicts a better familiarity of young people with new technologies. In literature, this group of young individuals is often referred to as "digital natives". By using advanced technology in their private lives, there is more freedom and confidence in dealing with Industry 4.0 elements at work.

\section{Discussion}

The research carried out in organizations within the automotive industry has shown an average level of knowledge on the technologies of Industry 4.0 while small differences in the understanding of individual technologies are evident. Noteworthy information was provided by dividing all surveyed employees into three groups comprising management, engineering and production employees. It was discovered that the highest knowledge of technology was presented by engineering employees with a declared knowledge range of $36.3-69.6 \%$. The second group that has a relatively high level of knowledge is management employees with a claimed knowledge range of $32.9-56.6 \%$. Production workers, on the other hand, are characterized by significantly lower knowledge than the two previously mentioned groups with declared knowledge ranging from 12.2 to 30.2 percent. These results suggest that some amount of work will be required by organizations to prepare their employees in terms of knowledge and awareness of Industry 4.0 technologies. Admittedly, it can be said that the knowledge of engineering employees and management staff is based at an average level and will most likely be sufficient for the implementation of current tasks. However, when planning and introducing new technological solutions which are inevitable in the automotive industry, this may prove to be insufficient. It is difficult to say whether these organizations and their top management are aware of the level of knowledge of particular groups of employees, or if the organizations have any action plans in place to improve their employees' knowledge. The authors of the article [33] draw attention to the different perceptions of competence relevance by different groups of employees, including management. Organizations need to plan a comprehensive set of activities in advance which should be aimed at increasing the knowledge of all groups of employees. Such a set of activities should refer to the development of employees in terms of competencies of different nature, which was also pointed out by the authors in the works [30,31]. In the model presented in the work [30] suggested development in four categories: technical, methodological, social and personal and in the model from the work [31] competencies are classified as technical, traversal and contextual. Failure to implement these activities or their partial implementation may lead to barriers in the introduction of new solutions that will significantly delay the process. From the conducted research, it can be concluded that the group most neglected in the knowledge of Industry 4.0 technologies are serial production workers. These employees' admittedly have a minimum level of knowledge needed to perform their daily tasks which could constitute a problem in the future when the organization deems it necessary to introduce fundamental changes, as these group of workers will be unprepared. The lack of adequate preparation by this group of employees will present a significant barrier to the introduction of I4.0 technological changes, which may prolong and in extreme cases hinder the process of change.

Similar results were obtained in other company case studies conducted in other European countries [26]. The authors consider the lack of knowledge about Industry 4.0 as 
one of the main barriers to the development of companies regardless of their size. They also pointed out the need to support entrepreneurs in implementing new technological solutions and in raising the awareness of employees [34]. According to Czech research, the fear of unfamiliar technology may be an obstacle to IT-based innovation. Researchers have indicated that gender and age are two differentiating variables. Women are more likely to fear technology and the changes associated with its introduction than men $[49,50]$. However, the research conducted in the automotive industry in Poland cannot confirm this observation due to the small percentage of women employed in the surveyed companies. The results of the research show a different trend related to the age of employees and fears of introducing elements of Industry 4.0. In this case study, the anxiety is stated by groups of older employees over the age of 50 years old while in the Czech research, the threat is felt by younger people ranging between 30 to 45 years old. Technology is treated as a modern method of streamlining work i.e., the link between automation and job loss is not seen. The anxiety about keeping one's job remains low and mainly concerns older workers. This presumption is influenced by the low level of unemployment in Poland and the good condition of the automotive industry. The perception of technology has positive connotations in Polish companies, especially in the collaboration of human work and robots. Younger employees have a better perception of changes at work due to having higher trust in applied technical solutions. More than $37 \%$ of the youngest employees described their trust in robots cooperating with humans as high or complete. As noted earlier by $\mathrm{F}$. Fukuyama, trust is an extremely important element in the development of a company and the entire economy. It can be concluded that the introduction of improvements based on IT in the surveyed companies is accepted rather as a natural order of things. An additional factor is having a positive attitude to acquiring new skills and competencies by employees. It is observed especially among engineering employees ( $84 \%$ of responses) and over $65 \%$ of the management employees who have declared the intention to improve their qualifications independently in addition to training offered by companies. The results obtained can be related to other publications that analyzed educational needs [42-45].

It should be recognized that the specificity of the Polish automotive industry determines the attitudes of employees towards their work. Low unemployment and a large number of young employees with a minimum of a secondary education allows for the increase of sense of security and greater openness to new technologies.

\section{Conclusions}

The authors in this case study conducted a survey on knowledge, openness to change, readiness to raise competence, trust in technology, and fear of technology on a sample of employees in Polish organizations within the automotive industry. A large number of results were obtained which have informed the formulation of interesting conclusions. The example of selecting companies from the automotive industry draws attention to the need for employees to have an appropriate level of knowledge about Industry 4.0 technologies. The division of employees into three groups proposed in this study introduces diversity and allows us to identify the most neglected group. The lack of needed knowledge in blue-collar workers employed in production may stand as a significant barrier to the introduction of new technological solutions. The research also shows that there are similar trends when it concerns trust in technology. Therefore, it is important for top management to be aware of the preparation of particular groups of workers and to take appropriate actions to improve this situation. Another important factor is the employees' openness to change and readiness to increase their competence level. In this study, these issues were related to the position and age of employees. The premise that blue-collar workers are less focused on acquiring new knowledge was confirmed. The lowest rate to openness to change was observed among the oldest employees. Consequently, this group should be supported in order to take full advantage of their experience as these activities and actions are essential for the overall development of the organization. 
The conducted research has provided universal information that can serve the top management at the stage of preparation for implementation of the Industry 4.0 concept. The top management should determine the knowledge of employees concerning the knowledge of issues related to the analyzed concept, preferably divided into groups. Activities should be prepared for each group of employees (information campaign, training, analysis of good practices) which are to influence the increase of knowledge and awareness of new technologies. These activities should lead to better preparation of employees for the implementation of changes and reduce their resistance towards changes.

The authors have also attempted to compare the obtained survey results with studies conducted in other countries to reach a conclusion on the similarities and differences of the analyzed issues. It has been observed, however, that the social aspect of Industry 4.0 has limited research in literature and so making comparisons will be unsuitable. In different publications, the use of various methods for measuring attitudes of employees makes it difficult to directly compare the results. Therefore, there is a need to conduct international comparative research that covers the field of Industry 4.0 occurring in the largest companies as well as small and medium-sized enterprises in a given country. The labor market and socio-cultural factors determine the perception of one's own work situation, therefore, the implementation of Industry 4.0 solutions may encounter diverse barriers in different countries.

It is vital to point out that this conducted research was limited to one region of a country and specific to companies within the automotive industry, which is only one branch of the economy. Extending the research to other regions and other industries would make it possible to further define the situation of an average Polish employee with respect to the 4 th industrial revolution.

Author Contributions: Conceptualization, M.J.L., B.R., K.K.; methodology, M.J.L., B.R., K.K.; software, M.J.L., B.R., K.K.; validation, M.J.L., B.R., K.K.; formal analysis, M.J.L., B.R., K.K.; investigation, M.J.L., B.R., K.K.; resources, M.J.L., B.R., K.K.; data curation, M.J.L., B.R., K.K.; writing-original draft preparation, M.J.L., B.R., K.K.; writing—review and editing, M.J.L., B.R., K.K.; visualization, M.J.L., B.R., K.K.; supervision, M.J.L., B.R., K.K.; project administration, M.J.L., B.R., K.K.; funding acquisition, M.J.L., B.R., K.K. All authors have read and agreed to the published version of the manuscript.

Funding: This research received no external funding.

Institutional Review Board Statement: Ethical review and approval were waived for this study, due to complete anonymity and voluntary participation in the research.

Informed Consent Statement: Not applicable.

Data Availability Statement: The data presented in this study are available on request from barbara.rozalowska@polsl.pl.

Conflicts of Interest: The authors declare no conflict of interest.

\section{References}

1. Pascual, D.G.; Daponte, P.; Kumar, U. Handbook of Industry 4.0 and SMART Systems; CRC Press: Boca Raton, FL, USA, 2019; ISBN 0-429-45575-5.

2. Sarı, T.; Güleş, H.K.; Yiğitol, B. Awareness and Readiness of Industry 4.0: The Case of Turkish Manufacturing Industry. Adv. Prod. Eng. Manag 2020, 15, 57-68. [CrossRef]

3. Longo, F.; Nicoletti, L.; Padovano, A. Smart Operators in Industry 4.0: A Human-Centered Approach to Enhance Operators' Capabilities and Competencies within the New Smart Factory Context. Comput. Ind. Eng. 2017, 113, 144-159. [CrossRef]

4. OECD. Job Creation and Local Economic Development 2018: Preparing for the Future of Work; Job Creation and Local Economic Development; OECD: Paris, France, 2018; ISBN 978-92-64-30533-5.

5. ADP. Workforce View in Europe 2018; The Workforce View 2018; ADP: Roseland, NJ, USA, 2018.

6. World Economic Forum. The Future of Jobs Report 2020; World Economic Forum: Cologny, Switzerland, 2020.

7. Bonekamp, L.; Sure, M. Consequences of Industry 4.0 on Human Labour and Work Organisation. J. Bus. Media Psychol. 2015, 6, 33-40. 
8. Kadir, B.A.; Broberg, O. Human-Centered Design of Work Systems in the Transition to Industry 4.0. Appl. Ergon. 2021, 92, 103334. [CrossRef] [PubMed]

9. Davies, R.; Coole, T.; Smith, A. Review of Socio-Technical Considerations to Ensure Successful Implementation of Industry 4.0. Procedia Manuf. 2017, 11, 1288-1295. [CrossRef]

10. Fantini, P.; Pinzone, M.; Taisch, M. Placing the Operator at the Centre of Industry 4.0 Design: Modelling and Assessing Human Activities within Cyber-Physical Systems. Comput. Ind. Eng. 2020, 139, 105058. [CrossRef]

11. Nelles, J.; Kuz, S.; Mertens, A.; Schlick, C.M. Human-Centered Design of Assistance Systems for Production Planning and Control: The Role of the Human in Industry 4.0. In Proceedings of the 2016 IEEE International Conference on Industrial Technology (ICIT), Taipei, Taiwan, 14-17 March 2016; IEEE: Piscataway, NJ, USA, 2016; pp. 2099-2104.

12. Lee, J.; Bagheri, B.; Kao, H.-A. A Cyber-Physical Systems Architecture for Industry 4.0-Based Manufacturing Systems. Manuf. Lett. 2015, 3, 18-23. [CrossRef]

13. Pacaux-Lemoine, M.-P.; Trentesaux, D. Ethical Risks of Human-Machine Symbiosis in Industry 4.0: Insights from the HumanMachine Cooperation Approach. IFAC-PapersOnLine 2019, 52, 19-24. [CrossRef]

14. Ahmad, N.; Shamsuddin, A.; Abu Seman, N.A. Industry 4.0 Implications on Human Capital: A Review. J. Stud. Manag. Plan. 2018, 4, 221-235.

15. Nardo, M.; Forino, D.; Murino, T. The Evolution of Man-Machine Interaction: The Role of Human in Industry 4.0 Paradigm. Prod. Manuf. Res. 2020, 8, 20-34. [CrossRef]

16. Krugh, M.; Mears, L. A Complementary Cyber-Human Systems Framework for Industry 4.0 Cyber-Physical Systems. Manuf. Lett. 2018, 15, 89-92. [CrossRef]

17. Gorecky, D.; Schmitt, M.; Loskyll, M.; Zühlke, D. Human-Machine-Interaction in the Industry 4.0 Era. In Proceedings of the 2014 12th IEEE International Conference on Industrial Informatics (INDIN), Porto Alegre, Brazil, 27-30 July 2014; IEEE: Piscataway, NJ, USA, 2014; pp. 289-294.

18. Demir, K.A.; Döven, G.; Sezen, B. Industry 5.0 and Human-Robot Co-Working. Procedia Comput. Sci. 2019, 158, 688-695. [CrossRef]

19. Gaughan, K.P.; Hirsch, P.M.; Blasi, J.R.; Freeman, R.B.; Kruse, D.L. The Citizen's Share: Putting Ownership Back into Democracy; SAGE Publications Sage: Los Angeles, CA, USA, 2014; ISBN 0001-8392.

20. International Competitiveness in the Context of the Development of Industry 4.0 (In Polish); Polska: Raport o konkurencyjności; Wydanie I.; Kowalski, A.M.; Weresa, M.A. (Eds.) Oficyna Wydawnicza SGH, Szkoła Główna Handlowa: Warszawa, Poland, 2019; ISBN 978-83-8030-314-0.

21. Ratnasingam, J.; Lee, Y.Y.; Azim, A.A.A.; Halis, R.; Liat, L.C.; Khoo, A.; Daud, M.M.M.; Senin, A.L.; Ab Latib, H.; Bueno, M.V. Assessing the Awareness and Readiness of the Malaysian Furniture Industry for Industry 4.0. Bioresources 2020, 15, 4866-4885. [CrossRef]

22. Liao, Y.; Deschamps, F.; Loures, E. de F.R.; Ramos, L.F.P. Past, Present and Future of Industry 4.0-a Systematic Literature Review and Research Agenda Proposal. Int. J. Prod. Res. 2017, 55, 3609-3629. [CrossRef]

23. Sony, M. Pros and Cons of Implementing Industry 4.0 for the Organizations: A Review and Synthesis of Evidence. Prod. Manuf. Res. 2020, 8, 244-272. [CrossRef]

24. Ejsmont, K. The Impact of Industry 4.0 on Employees-Insights from Australia. Sustainability 2021, 13, 3095. [CrossRef]

25. Ślusarczyk, B. Industry 4.0: Are We Ready? Pol. J. Manag. Stud. 2018, 17, 232-248. [CrossRef]

26. Türkeș, M.C.; Oncioiu, I.; Aslam, H.D.; Marin-Pantelescu, A.; Topor, D.I.; Căpușneanu, S. Drivers and Barriers in Using Industry 4.0: A Perspective of SMEs in Romania. Processes 2019, 7, 153. [CrossRef]

27. Nick, G.; Szaller, Á.; Bergmann, J.; Várgedő, T. Industry 4.0 Readiness in Hungary: Model, and the First Results in Connection to Data Application. IFAC-PapersOnLine 2019, 52, 289-294. [CrossRef]

28. Sommer, L. Industrial Revolution-Industry 4.0: Are German Manufacturing SMEs the First Victims of This Revolution? J. Ind. Eng. Manag. 2015, 8, 1512-1532. [CrossRef]

29. Naderi, M.; Ares, E.; Peláez, G.; Prieto, D.; Araújo, M. Sustainable Operations Management for Industry 4.0 and Its Social Return. IFAC-PapersOnLine 2019, 52, 457-462. [CrossRef]

30. Hecklau, F.; Galeitzke, M.; Flachs, S.; Kohl, H. Holistic Approach for Human Resource Management in Industry 4.0. Procedia Cirp 2016, 54, 1-6. [CrossRef]

31. Fitsilis, P.; Tsoutsa, P.; Gerogiannis, V. Industry 4.0: Required Personnel Competences. Industry 4.0 2018, 3, $130-133$.

32. Benešová, A.; Tupa, J. Requirements for Education and Qualification of People in Industry 4.0. Procedia Manuf. 2017, 11, 2195-2202. [CrossRef]

33. Grzelczak, A.; Kosacka, M.; Werner-Lewandowska, K. Employees Competences for Industry 4.0 in Poland-Preliminary Research Results. In DEStech Transactions on Engineering and Technology Research; DEStech Publications, Inc.: Lancaster, PA, USA, 2018; pp. 130-144.

34. Sasiadek, M.; Basl, J. Awareness and the level of implementation of the Industry 4.0 concept in selected Polish and Czech enterprises (in Polish). In Innowacje w Zarzadzaniu i Inżynierii Produkcji; Oficyna Wydawnicza Polskiego Towarzystwa Zarządzania Produkcją: Opole, Poland, 2018; Volume II, pp. 189-198.

35. Basl, J. Pilot Study of Readiness of Czech Companies to Implement the Principles of Industry 4.0. Manag. Prod. Eng. Rev. 2017, 8 , 3-8. [CrossRef] 
36. Vrchota, J.; Mařiková, M.; Řehoř, P.; Rolínek, L.; Toušek, R. Human Resources Readiness for Industry 4.0. J. Open Innov. Technol. Mark. Complex. 2020, 6, 3. [CrossRef]

37. Ersoz, F.; Merdin, D.; Ersoz, T. Research of Industry 4.0 Awareness: A Case Study of Turkey. Econ. Bus. 2018, 32, 247-263. [CrossRef]

38. Kadir, B.A.; Broberg, O. Human Well-Being and System Performance in the Transition to Industry 4.0. Int. J. Ind. Ergon. 2020, 76, 102936. [CrossRef]

39. Saniuk, S.; Grabowska, S.; Gajdzik, B. Social Expectations and Market Changes in the Context of Developing the Industry 4.0 Concept. Sustainability 2020, 12, 1362. [CrossRef]

40. Müller, J.M. Assessing the Barriers to Industry 4.0 Implementation from a Workers' Perspective. IFAC-PapersOnLine 2019, 52, 2189-2194. [CrossRef]

41. Ravina-Ripoll, R.; Núñez-Barriopedro, E.; Evans, R.D.; Ahumada-Tello, E. Employee Happiness in the Industry 4.0 Era: Insights from the Spanish Industrial Sector. In Proceedings of the 2019 IEEE Technology \& Engineering Management Conference (TEMSCON), Atlanta, GA, USA, 12-14 June 2019; IEEE: Piscataway, NJ, USA, 2019; pp. 1-5.

42. Motyl, B.; Baronio, G.; Uberti, S.; Speranza, D.; Filippi, S. How Will Change the Future Engineers' Skills in the Industry 4.0 Framework? A Questionnaire Survey. Procedia Manuf. 2017, 11, 1501-1509. [CrossRef]

43. Shamim, S.; Cang, S.; Yu, H.; Li, Y. Management Approaches for Industry 4.0: A Human Resource Management Perspective. In Proceedings of the 2016 IEEE Congress on Evolutionary Computation (CEC), Vancouver, BC, Canada, 24-29 July 2016; IEEE: Piscataway, NJ, USA, 2016; pp. 5309-5316.

44. Karimulla, U.; Gupta, K.; Mashinini, M.; Nkosi, M.; Anghel, C. Industry 4.0 and the Role of Human Resource Development in the South African Fabrication and Construction Industry. In Proceedings of the 5th NA International Conference on Industrial Engineering and Operations Management, Detroit, MI, USA, 10-14 August 2020; IEOM Society International: Detroit, MI, USA, 2020; pp. 3219-3228.

45. Sima, V.; Gheorghe, I.G.; Subić, J.; Nancu, D. Influences of the Industry 4.0 Revolution on the Human Capital Development and Consumer Behavior: A Systematic Review. Sustainability 2020, 12, 4035. [CrossRef]

46. Hamada, T. Determinants of Decision-Makers' Attitudes toward Industry 4.0 Adaptation. Soc. Sci. 2019, 8, 140. [CrossRef]

47. Vaidya, S.; Ambad, P.; Bhosle, S. Industry 4.0-A Glimpse. Procedia Manuf. 2018, 20, 233-238. [CrossRef]

48. Safar, L.; Sopko, J.; Dancakova, D.; Woschank, M. Industry 4.0—Awareness in South India. Sustainability 2020, 12, 3207. [CrossRef]

49. Soukupová, N.; Adamová, M.; Krninská, R. Industry 4.0: An Employee Perception (Case of the Czech Republic). Acta Univ. Agric. Et Silvic. Mendel. Brun. 2020, 68, 637-644. [CrossRef]

50. Židová, N.; Adamová, M.; Krninská, R. Industry 4.0 as a Potential Threat for Czech Employees? In Proceedings of the International Scientific Conference Economic and Social Policy, Čeladná, Czech Republic, 4-6 September 2018; Volume 10. 